\title{
Transposition of the 2014 European Directives on public procurement by France
}

\author{
Kawthar Ben Khelil
}

\begin{abstract}
The French public procurement code should be published in the next weeks ${ }^{1}$. This project initiated by the French Government gave rise to a public consultation between 23 April and 29 May 2018; it is aimed at grouping together, without any amendments to current rules, all existing provisions relating to public procurement law (all contracts qualifying as public contracts and concessions), according to a consistent plan $^{2}$, in order to make the relevant legal framework clearer and more accessible.
\end{abstract}

As of this day however, French rules relating to the conclusion and performance of public procurement contracts are contained in ordinance (ordonnance) n 2015-899 of 23 July 2015 relating to public contracts (hereinafter referred to as the "Ordinance") and its implementation decree (décret), $\mathrm{n}^{\circ} 2016-360^{3}$, of 25 March $2016^{4}$ (hereinafter referred to as the "Decree"), that have implemented into domestic law the new European directives on public procurement ${ }^{5}$. They entered into force on 1 April 2016.

This contribution is aimed at providing an overall presentation of the significant changes resulting from the implementation into French law of EU Directives 2014/24 and 2014/25 without claiming to be exhaustive.

\section{Keywords:}

Single legal framework; easier access to public procurement; simplification of available tender procedures; E-procurement

\section{A simplified legal framework in relation to public contracts}

\subsection{A single legal instrument for all French contracting authorities}

Under French domestic law, until the entry into force of the Ordinance, contracting authorities used to be subject either to the code des marchés publics (central government entities, a few central public institutions, public local entities, public hospitals...) or to ordinance $\mathrm{n}^{\circ} 2005-649$ of 6 June 2005 regarding public and private entities which are not governed by the code des marchés publics (other central public institutions, public national companies).

Also, public-private partnership contracts (PPPs) previously referred to as "contrats de partenariat" - and now referred to as "marchés de partenariat" - were governed by ordinance n 2004-559 of 17 June 2004.

\footnotetext{
${ }^{1}$ This code shall be adopted within 24 months as of the publication of Act $n^{\circ}$ 2016-1691 of 9 December 2016 relating to transparency, the fight against corruption and the modernization of economic life (cf. article 38 of this Act).

${ }^{2}$ Composed of three parts: definitions and scope, public contracts, concessions.

${ }^{3}$ This Decree applies to all procurement contracts, except for procurements contracts in relation to defence and security referred to in article 6 of the Ordinance (see decree $n^{\circ}$ 2016-361 of 25 March 2016 relating to procurement contracts on defence and security).

${ }^{4}$ Whereas French concession contracts are governed by order n ${ }^{\circ} 2016-65$ of 29 January 2016 and its implementation decree, $\mathrm{n}^{\circ}$ 2016-86, of 1 February 2016. These legislative and regulatory provisions have transposed into French law Directive $2014 / 23 / \mathrm{EU}$ on the award of concession contracts.

${ }^{5}$ Directives 2014/24/UE of 26 February 2014 on public procurement and repealing Directive 2004/18/EC and 2014/25/UE of 26 February 2014 on procurement by entities operating in the water, energy, transport and postal services sectors and repealing Directive 2004/17/EC.
} 
In addition, framework agreements (accords-cadres) are defined as a category of public contracts with one or more economic operators the purpose of which is to establish the terms relating to order forms (bons de commande) to be issued or the terms governing the subsequent public contracts to be concluded during a given period, in particular with regard to price and, where appropriate, the quantity envisaged (Ordinance, article 4). Public contracts with order forms (marchés à bons de commande) have therefore become a sub-category of framework agreements as opposed to a different type of public contract.

All public contracts - including marchés de partenariat ${ }^{6}$ - executed by any French contracting authorities - and contracting entities - are now governed by only one legal instrument under French law: the Ordinance, together with the Decree.

\subsection{Any procurement contract concluded by a French public entity is governed by French administrative law}

Pursuant to article 3 of the Ordinance, procurement contracts executed by French public entities are governed by French administrative law, which entails a certain number of specific rules which depart from common rules (exorbitantes du droit commun) and general principles related to administrative contracts resulting mainly from French administrative case law, whether or not expressly provided for by the contract, among which:

- right for the public entity to modify unilaterally the contract, subject to indemnification of the contractor (CE, 11 March 1910, Compagnie générale française des tramways, $\mathrm{n}^{\circ}$ 16178: Rec., p. 216);

- $\quad$ right of unilateral termination by the public entity, for grounds of public interest, even failing an express clause in this respect (CE, Ass., 2 May 1958, Distillerie de Magnac-Laval, n $32401-$ 32402-32507-34562: Rec., p. 246) or for breach by the economic operator;

- $\quad$ prohibition, in principle, for the contractor to invoke the exception d'inexécution, i.e. the defence consisting in ceasing to perform the contract on the ground that the other party has breached its contractual obligations (CE, 7 January 1976, Ville d'Amiens, n 92888: Rec., p. 11) ${ }^{7}$.

This also results in French administrative courts having jurisdiction over any claims filed by the parties or third parties to a public contract in relation to the conclusion, interpretation or performance of such contract, whereas there used to be a distribution between French administrative and judicial courts under the previous rules.

\section{An easier access to public contracts}

\subsection{Division into lots}

Under article 32 of the Ordinance, public contracts - except for global public contracts mentioned in section 4 of the Ordinance - must in principle be divided into lots unless their subject-matter does not enable separate performances to be identified. Contracting authorities can nevertheless decide not to divide a public contract into lots; they must in this hypothesis indicate the main

\footnotetext{
${ }^{6}$ Ordinance, article 4.

${ }^{7}$ It is to be noted that the contractor may, however, now have the right to terminate unilaterally a public contract in the event that the contracting authority has breached its contractual obligations, provided that (i) the contract is not related to the very operation of a public service and (ii) the conditions for such a unilateral termination are provided for by the contract (CE, 8 October 2014, Société Grenke location, n 370644 ). The contractor's right to terminate the contract, which is therefore limited to a certain kind of contracts, is also strictly regulated: first, the contractor cannot terminate the contract without having first enabled the contracting authority to oppose the termination for grounds connected with the public interest (e.g. requirements of the public service); secondly, where grounds connected with the public interest are raised by the contracting authority, the contractor shall continue to perform the contract; otherwise the contract could be terminated exclusively against the contractor, which shall bear the costs incurred. The grounds of public interest can nevertheless be challenged before an administrative court in order to obtain the judicial termination of the contract.
} 
reasons for their choice (in the procurement documents or the individual report in relation to contracts the value of which is above European thresholds).

Regarding public contracts divided into lots, the contracting authority's right to limit either the number of lots for which the same economic operator may submit a tender or the number of lots which may be awarded to the same tenderer is also introduced into article 32 of the Ordinance, in line with the previous domestic case law (CE, 20 February 2013, Société Laboratoire Biomnis, $\mathrm{n}^{\circ}$ $363656)^{8}$.

\subsection{European Single Procurement Document}

According to the 2014 EU Directives ${ }^{9}$, contracting authorities must accept the European Single Procurement Document ("ESPD") at the time of submission of requests to participate or submission of tenders.

This document consists of an updated self-declaration as a preliminary evidence in replacement of certificates issued by public authorities or third parties confirming that the economic operator is not in one of the situations in which it must or may be excluded; it meets the selection criteria set out by the contracting authority as to economic and financial standing or technical and professional ability; where applicable, it fulfils the objective rules and criteria that have been set out in relation to the reduction of the number of otherwise qualified candidates to be invited to participate. The ESPD which has already been used in a previous procurement procedure may be reused by the economic operator if it confirms that the information contained therein continues to be correct. The contracting authority is obliged to verify the correctness of the information given in the ESPD only regarding the presumptive best bidder.

The use of this document should therefore result in considerable simplification for the benefit of both economic operators and contracting authorities: it should provide substantial relief for companies regarding cross-border applications and small and medium-sized enterprises; in addition, this should allow contracting authorities to save time during the tender process.

Nevertheless, in practice, it is to our knowledge not widely used as of this day.

\subsection{Right to invite tenderers to regularize an irregular tender}

Even though irregular tenders submitted within the framework of open or restricted procedures or procedures without negotiation must be eliminated, contracting authorities may invite tenderers to regularize their tenders provided that they are not abnormally low ${ }^{10}$.

This should allow tenders with minor irregularities to be regularized instead of being automatically eliminated.

\section{Operations excluded from the scope of the Ordinance}

\subsection{Specific exclusions for service contracts}

New specific exclusions have been inserted into article 14 of the Ordinance, regarding service contracts, notably:

- $\quad$ public passenger transport services by rail or metro (considering specific rules in this field ${ }^{11}$ ),

\footnotetext{
${ }^{8}$ Cf. also Decree, article 12.

${ }^{9}$ Cf. Directive 2014/24/EU, article 59

${ }^{10}$ Decree, article 59.

${ }^{11}$ Regulation (EC) n 1370/2007 of the European Parliament and of the Council of 23 October 2007 on public passenger transport services by rail and by road and repealing Council Regulations (EEC) $n^{\circ} 1191 / 69$ and $n^{\circ} 1107 / 70$.
} 
- loans, whether or not in connection with the issue, sale, purchase or transfer of securities or other financial instruments,

- specific service contracts (firefighting and rescue services, emergency services, nuclear security, ambulance except for services consisting exclusively in the transport of patients) awarded to a non-profit-making legal entity.

\section{2 "In house" exclusion}

Exclusions in relation to cooperation between contracting authorities are also implemented into French law by the Ordinance: the conditions under which contracting authorities may conclude contracts with each other without being held to comply with the requirements of public procurement law are set forth within.

In particular, pursuant to the "in house" theory created by the European Court of Justice's case law, the criteria for a contracting authority to award a contract directly to a legal entity they control have been broadly transcribed in the EU directives and French law ${ }^{12}$.

The notion of "control similar to that exercised over its own departments" is defined as the situation where the contracting authority exercises a decisive influence over both the strategic objectives and significant decisions of the controlled entity ${ }^{13}$.

The "in house" exception can now be cascaded as another contracting authority may come in between the controlling authority and the controlled entity, either itself in an "in house" situation or laterally (between procurers controlled by the same contracting authority).

Additionally, the "in house" situation can result from a control exercised jointly by several contracting authorities ${ }^{14}$.

Whereas the code des marchés publics required that the essential part of the controlled entity's activity be exercised for the controlling authority, this criterion is not quantified, in line with the provisions of the EU Directives: more than $80 \%$ of the activities of the controlled legal entity must be carried out in the performance of tasks it has been entrusted by the controlling contracting authority or by other legal entities controlled by that contracting authority.

Private capital participation in the controlled legal person is henceforth allowed ${ }^{15}$, whether indirectly or directly; in the latter case however, the participation must be non-controlling and non-blocking, required by national legislative provisions in conformity with the Treaties and not exert a decisive influence on the controlled legal entity.

Furthermore, "in house" relations do not necessarily apply downward only: public contracts concluded by the controlled legal entity with the controlling contracting authority also benefit from this exception.

\subsection{Contractual cooperation between contracting authorities}

According to article 18 of the Ordinance, contracting authorities may conclude contracts without having to apply the Ordinance and Decree provided that:

\footnotetext{
12 Ordinance, article 17.

${ }^{13}$ For an example in the European case law: ECJ, 19 April 2007, Parking Brixen GmbH, Gemeinde Brixen, Stadtwerke Brixen $A G, \mathrm{C}-458 / 03$.

${ }^{14}$ The condition of joint control is fulfilled not only where the contracting authorities hold capital in the entity but also play a role in its managing bodies, but the Ordinance allows the participation in the managing bodies to be indirect for several or all of the contracting authorities considered, which makes this condition more flexible than in the previous case law (ECJ, 29 November 2012, Econord SpA, C-182/11, et CE, 6 November 2013, n 365079).

${ }^{15}$ Whereas it was formerly excluded by case law: ECJ, 11 January 2005, Stadt Halle, RPL Recyclingpark Lochau GmbH, C$26 / 03$.
} 
- the contract establishes or implements a cooperation between the participating contracting authorities with the aim of ensuring that the public services they have to perform are provided with a view to achieving objectives they have in common

- the cooperation is driven solely by considerations relating to the public interest, and

- the contracting authorities perform on the open market less than $20 \%$ of the activities covered by the cooperation.

These criteria would deserve to be clarified by case law.

\section{Publication thresholds}

European thresholds ${ }^{16}$ are currently as follows:

- $\quad$ regarding supply and services contracts:

○ in respect to contracting authorities: $€$ 144,000 for central government authorities and central public institutions, or $€ 221,000$ as regards public local entities;

$\circ \quad$ in relation to contracting entities: $€ 443,000$, and

- $\quad$ as regards public works contracts: $€ 5,548,000^{17}$.

Above European thresholds, one of the following tender procedures must be used:

- an appel d'offres (either open or restricted procedure) in principle,

- a competitive procedure with negotiation (contracting authorities) or a negotiated procedure with prior publication (contracting entities),

- a competitive dialogue ${ }^{18}$.

A contract notice must be published in the Official Journal of the European Union.

For contracts whose estimated value is below the European thresholds, the conditions for the publication and competition processes can be freely determined (procédure adaptée) by the contracting authority, provided that they are adapted to the object and specificities of the contract, the number and location of the economic operators likely to be interested in the contract, and the circumstances of the contract to be concluded (Decree, article 27). Contracting authorities may also resort to the procedure referred to as "adaptée" for contracts for social and other specific services, regardless of their value (Decree, article 28).

The Ordinance and Decree provide for intermediary thresholds in addition to those resulting from European directives:

- contracts below $€$ 25,000 may be concluded without prior publication (Decree, article $30-\mathrm{I}-8^{\circ}$ ). The contracting authority must nevertheless choose a relevant offer, make good use of public money and refrain from systematically contracting with the same economic operator when the contracting authority's needs may be met by several other operators.

- $\quad$ For contracts that are (i) executed by the French Government, public national institutions that do not have an industrial and commercial nature, public local entities and institutions, and (ii) worth between $€$ 90,000 and the above-mentioned European thresholds, a contract notice has to be published either in the Bulletin Officiel des Annonces des Marchés Publics (BOAMP) or in a newspaper authorized to publish legal announcements. The contracting authority must appreciate whether, according to the nature or amount of the products, services or works concerned, a notice in a specialised newspaper corresponding to the economic sector involved or

\footnotetext{
${ }^{16}$ Excluding VAT.

${ }^{17}$ Notice relating to thresholds applicable to public contracts and to the list of central government authorities in public procurement law, $\mathrm{n}^{\circ} 171$ (published on 31 December 2017 in the Official Journal of the French Republic).

${ }^{18}$ Ordinance, article 42 .
} 
in the Official Journal of the European Union is in addition necessary to guarantee an appropriate information for reasonably vigilant economic operators that might be interested in the contract (Decree, article $\left.34-\mathrm{I}-1^{\circ}-\mathrm{b}\right)$.

In any case, the fundamental principles of public procurement, such as equal access to public procurement and transparency, must be observed regardless of the value of the contract (even below $€ 25,000)$.

\section{Simplification in respect of available tender procedures}

\subsection{Easier recourse to negotiated procedures}

Whereas a contracting authority is free to choose among the open and the restricted procedure ${ }^{19}$, they may use a negotiated procedure only under certain circumstances. Nonetheless hypotheses of recourse to negotiated procedures have been significantly widened.

The negotiated procedure without prior publication of a contract notice (marché négocié sans publicité ni mise en concurrence préalables) may be used in the specific cases and circumstances referred to in article 30 of the Decree, where using an open or restricted procedure without negotiation is not likely to lead to a satisfactory outcome, for example:

- insofar as is strictly necessary when, for reasons of extreme urgency brought about by events unforeseeable for and not attributable to the contracting authority, the time limits for the open procedure, restricted procedure, negotiated procedure with prior publication or competitive dialogue cannot be complied with;

- where no tenders, no suitable tenders, no requests to participate or no suitable requests to participate have been submitted in response to (i) an open procedure or a restricted procedure carried out by a contracting authority, (ii) a tender procedure carried out by a contracting entity, or (iii) a tender procedure related to (a) a contract whose value is below the European thresholds or (b) related to social or other specific services or legal services involving the representation of the contracting authority in judicial proceedings, provided that the initial conditions of the public contract are not substantially altered;

- where the works, supplies or services can be supplied only by a particular economic operator for any of the following reasons: (i) the aim of the procurement is the creation or acquisition of a unique work of art or artistic performance; (ii) for technical reasons; (iii) the protection of exclusive rights, including intellectual property rights.

Contracting authorities may apply a competitive procedure with negotiation (procédure concurrentielle avec négociation) or competitive dialogue, in the specific cases and circumstances referred to in article 25-II of the Decree:

- $\quad$ the needs of the contracting authority require adapting readily available solutions;

- $\quad$ the needs of the contracting authority include innovative solutions;

- the public contract contains design performances;

- the contract cannot be awarded without prior negotiations because of specific circumstances related to the nature, the complexity or the legal and financial make-up of the contract or because of the risks attached to it;

- the technical specifications cannot be established with sufficient precision by the contracting authority with reference to a standard, European technical assessment, common technical specification or technical reference;

\footnotetext{
${ }^{19}$ Ordinance, article 42; Decree, article 66.
} 
- $\quad$ where an open or restricted procedure resulted only in irregular or unacceptable tenders within the meaning of article 59 of the Decree, provided that the initial conditions of the public contract are not substantially altered. The contracting authority is not held to publish a contract notice when it allows to participate in the procedure only the tenderers which, during the prior open or restricted procedure, submitted tenders in accordance with the formal and deadline requirements of the procurement procedure.

In the utility services sectors, the use of the negotiated procedure with prior publication (procédure négociée avec mise en concurrence préalable) by contracting entities is always possible (Decree, article 26).

\subsection{Right to examine tenders before candidatures within the framework of an open procedure}

In open procedures contracting authorities may examine tenders before candidatures (more specifically, the absence of grounds of exclusion and the fulfilment of the selection criteria set out in the tender documents), which may allow them to check only the candidature of the tenderer which has submitted the most economically advantageous tender ${ }^{20}$.

However, the contracting authority must ensure that this verification is carried out in an impartial and transparent manner so that the public contract is not awarded to a tenderer that should have been excluded.

\subsection{Innovation partnership}

A new kind of public contract, i.e. the innovation partnership, was implemented into French law before the enactment of the Ordinance with the publication of decree $n^{\circ} 2014-1097$ of 26 September $2014^{21}$. This contract should enable the award of research and development supplies, services or works, including the subsequent acquisition of the resulting products, services or works. It can only be resorted to provided that it complies with needs which cannot be satisfied by the acquisition of products, services or works already available on the market, which implies that the contracting authority will have to first carry out a thorough and precise study in order to check that their needs cannot be covered by already existing solutions.

An innovation partnership can be concluded with either one or more economic operators. In the latter case, this must be specified by the contracting authority in the tender documents and the innovation partnership is then composed of several individual contracts that must be performed separately.

Above European thresholds, the contracting authority may use the competitive procedure with negotiation or the negotiation procedure with prior publication subject to the specificities laid down by the Decree regarding innovation partnerships. In particular, the publication of a contract notice is mandatory. The contracting authority must identify the need for innovative products, services or works so as to enable economic operators to determine the nature and scope of the solution required and to decide whether to request to participate in the tender procedure. The tender documents must specify which elements of description must constitute the minimum requirements to be met by all tenders.

At this stage it is too soon to know whether this specific type of contract and procurement procedure will be used by many contracting authorities.

\footnotetext{
${ }^{20}$ Decree, article 68.

${ }^{21}$ It is now provided for by articles 93 to 95 of the Decree.
} 


\section{E-procurement}

On 1 October $2018^{22}$, the use of electronic means of communication ("e-procurement") will become mandatory for all contracting authorities or entities regardless of the value of the contract ${ }^{23}$. However, exceptions to this obligation must apply: for example, contracts the value thereof is below $€ 25,000$ or contracts for social and other specific services mentioned in article 28 of the Decree will be exempt from e-procurement ${ }^{24}$.

More specifically, when e-procurement is mandatory, electronic means have to be used concerning the essential elements of a procurement procedure, such as procurement documents and the submission of tenders ${ }^{25}$. All contracting authorities and entities must also offer unrestricted and full direct access - by electronic means and free of charge - to the electronic device used in relation to public procurement ${ }^{26}$.

Currently, several kinds of e-procurement platforms can be used by French contracting authorities: platforms proposed by private economic operators offering every function required by French and European public procurement law; numerous platforms developed by one public authority for its own needs; shared platforms developed by a grouping of public authorities for their own use.

The resort to e-signature has become optional by tenderers, under the current rules. It is up to the relevant contracting authority to decide whether it wishes to compel economic operators - in the contract notice or the tender rules within the framework of the relevant tender procedure - to sign bids electronically ${ }^{27}$. Executing a public contract electronically is also a faculty ${ }^{28}$.

\section{Traceability and transparency of decision-making in procurement procedures}

Directive 2014/24/EU highlights that traceability and transparency of decision-making in procurement procedures is essential for ensuring sound procedures, in particular efficiently fighting corruption and fraud. Contracting authorities should consequently keep copies of concluded highvalue contracts ${ }^{29}$, in order to provide access to those documents to interested parties in accordance with applicable rules on access to documents ${ }^{30}$.

After 1 October 2018, all contracting authorities and entities must offer unrestricted and full direct access - by electronic means and free of charge - to the essential data ${ }^{31}$ of any procurement procedure for public contracts and concessions whose value is equal to or exceeds $€ 25,000$ (excluding VAT), except for information the disclosure of which would disturb public order ${ }^{32}$.

\footnotetext{
${ }^{22}$ This has been already imposed on central purchasing bodies (centrales d'achat) since 1 April 2017.

${ }^{23}$ Decree, article 39.

${ }^{24}$ Decree, article 41.

${ }^{25}$ Decree, article 42.

${ }^{26}$ Decree, articles 39 and 42 .

${ }^{27}$ Ministerial reply to the written question of a member of Parliament, n 21405: JO Sénat, 16 June 2016 , p. 2691.

${ }^{28}$ Ordinance, article 102.

${ }^{29}$ Ordinance, article 57; Decree, article 108.

${ }^{30}$ Cf. French code of relations between the public and administration, articles L. 300-1 and seq.

${ }^{31}$ Including the nature and subject-matter of the public contract, its term, its value and main financial terms (Ordinance, article 56, Decree, article 107).

${ }^{32}$ Arrêté of 14 April 2017 relating to essential data in public procurement (NOR: ECFM1637256A). Motorway concessionaires have had to do so since 1 January 2018 (decree $n^{\circ}$ 2017-1816 of 28 December 2017 on the regulation of contracts in the field of motorways).
} 


\section{Modification of contracts during their term}

Cases where existing public contracts may be modified during their term without a new tender procedure being required are set out more precisely than before in article 139 of the Decree.

In substance, public contracts may be amended, in particular when:

- the modifications, regardless of their amount, have been provided for in the initial procurement documents in clear, precise and unequivocal review clauses, or options, provided that they do not provide for modifications that would alter the overall nature of the contract;

- additional works, services or supplies by the original contractor have become necessary and were not included in the initial procurement where (i) a change of contractor (a) cannot be made for economic or technical reasons (e.g., requirements of interchangeability and interoperability with existing equipment, services or installations procured under the initial procurement) and (b) would cause significant inconvenience or substantial duplication of costs for the contracting authority, (ii) any increase in price does not exceed $50 \%$ of the value of the original contract;

- the need for modification has arisen from circumstances that a diligent contracting authority could not foresee, (i) the modification does not alter the overall nature of the contract, and (ii) any increase in price of each modification (provided that consecutive modifications are not aimed at circumventing the rules of the Ordinance) shall not exceed $50 \%$ of the value of the original contract;

- a new contractor replaces the one to which the contracting authority had initially awarded the contract as a consequence of either (i) an unequivocal review clause or option complying with the above-mentioned criteria, or (ii) universal or partial succession into the position of the initial contractor following corporate restructuring, provided that (i) this does not entail other substantial modifications to the contract, (ii) this is not aimed at circumventing the rules of the Ordinance and (iii) the new contractor fulfils the criteria for qualitative selection initially set out by the contracting authority;

- the modifications are not substantial, regardless of their amount, this being specified that indications to assess whether a modification is substantial are provided by the Decree;

- the amount of the modifications is below (i) the European thresholds and (ii) $15 \%$ of the initial amount in respect of public works contracts or 10\% regarding supplies and services.

A reading grid of these provisions should be provided by European and French case law in the future.

\section{Conclusion: major changes brought into French public procurement law by the transposition of the 2014 EU Directives on public procurement}

The main major change resulting from the transposition into French law by the transposition of the 2014 EU Directives on public procurement consists in gathering in one single legal framework (i.e. the Order and the Decree) all rules applicable to the conclusion and performance of public procurement contracts whereas these rules were formerly spread in $17^{33}$ legal instruments, in particular the code des marchés publics, ordinance n²005-649 of 6 June 2005 and ordinance $n^{\circ} 2004$ 559 of 17 June 2004 on public-private partnership contracts.

The Order should also allow an easier access to public procurement, notably for small and mediumsized enterprises, among other things by extending to a certain extent the obligation to divide procurement contracts into lots and by establishing the European Single Procurement Document.

\footnotetext{
${ }^{33}$ According to the French Ministry of economy in July 2015.
} 
On 1 October 2018, the use of e-procurement will become mandatory for all contracting authorities or entities involved in public contracts whose value exceeds $€ 25,000$ (excluding VAT). Some public contracts, especially public contracts for social and other specific contracts, will nevertheless be exempt from this obligation. 